\title{
Analysis of pheochromocytomas / paragangliomas from Eastern Slovakia
}

\author{
M. FELSOCI ${ }^{1}$, I. LAZUROVA ${ }^{1, *}$, H. WAGNEROVA ${ }^{1}$, M. SVAJDLER ${ }^{2}$ \\ ${ }^{1} 1^{\text {st }}$ Department of Internal Medicine, Louis Pasteur University Hospital and Medical Faculty of University of P. J. Šafárik in Košice, Košice, \\ Slovakia; ${ }^{2}$ Department of pathology, Louis Pasteur University Hospital, Košice, Slovakia \\ ${ }^{*}$ Correspondence: ivica.lazurova@upjs.sk
}

Received November 29, 2012/ Accepted January 16, 2012

\begin{abstract}
This multi centre observational cohort study gives a view about the occurrence, clinical and laboratory presentation, localization, histological type and genetic background of pheochromocytoma (PHEO) and paraganglioma (PGL) in Eastern Slovakia. It included 28 patients (18 women +10 men), of which 23 were diagnosed to have PHEO $(82,1 \%)$ and 7 patients (25\%) suffered from PGL with retroperitoneal, inguinal/pelvic and mediastinal distribution. Arterial hypertension was the major symptom present in $86 \%$ with slight dominance of paroxysmal form (58\%). In 3 cases (10,7\%), the diagnosis was gained after differentiation of adrenal incidentaloma in asymptomatic patients. Five patients $(17,8 \%)$ were classified to have malignant form of the disease. 9 patients $(32,1 \%)$ were confirmed to have hereditary form - five of them $(17,8 \%)$ with familiar medullar thyroid cancer (FMTC) and mutations in RET gene classified as multiple endocrine neoplasia $2 \mathrm{~A}$ and 4 patients $(14,3 \%)$ with germline mutations of SDHB gene, respectively. There was found a relatively high occurrence of other co-morbidities: thyroid disease in 20 patients $(71,4 \%)$, impairment of glucose metabolism in 11 patients $(39,3 \%)$ and apart from FMTC, 4 patients $(14,3 \%)$ suffered also from other malignancy. Together with a bigger size of the primary tumor $(6,6 \mathrm{~cm})$, higher concentrations of metanephrines and prevalence of extra-adrenal tumors, malignant and hereditary forms, we suppose genetic and environmental factors of Eastern Slovakia may play a role in the etiopathogenesis of the tumors.
\end{abstract}

Key words: pheochromocytoma, paraganglioma, thyroid, diabetes mellitus, genetics, environmental

Pheochromocytomas (PHEOs) and paragangliomas (PGLs) are rare neuroendocrine tumors deriving in $85 \%$ from adrenomedullary tissue (PHEO) and in 15\% from extra-adrenal chromaffin tissue (PGL) $[1,2,3]$. Thanks to their ability to produce and secrete catecholamines, they represent secondary endocrine cause of paroxysmal or sustained arterial hypertension that is potentially treatable - surgically correctable in most cases. They are responsible for $0,05-0,1 \%$ of all cases of arterial hypertension with an estimated incidence 3-8 cases/1000000 inhabitans/1 year [4-6]. However, as a result of commonly unpredictable nature of this secretion, the clinical presentation is highly variable from poor to malignant and potentially lethal if not correctly or quickly diagnosed and treated. The incidence of metastatic PHEO/PGL ranges from 3\% to 36\% depending on the genetic background and tumor localization [6-10]. Due to evaluation of metanephrines, O-methylated metabolites of catecholamines that are produced continuously within chromatic tumor cells and independently of highly variable release of catecholamines, the diagnosis is now much more easier than previously, however if suspected [11-17]. Plasma- free metanephrines represent accessible diagnostic tool with $99 \%$ sensitivity and specificity of $89 \%[1,13]$.

Although the majority of tumors occur sporadically, inherited forms represent almost $24 \%$ of all cases $[18,19]$. To date, at least nine genes mutations have been described to be responsible for hereditary forms of these tumors: RET gene in multiple endocrine neoplasia type 2 (MEN2), von HippelLindau (VHL) gene in VHL syndrome, neurofibromatosis type 1 (NF1) gene in von Recklinghausen's disease [20-22]. More recently, germline mutations of genes encoding 4 subunits of succinate dehydrogenase (SDHA, SDHB, SDHC and SDHD), of transmembrane protein 127 (TMEM127) gene and tumor suppressor susceptibility gene MAX (MYC-associated factor $\mathrm{X})$ have been identified to be associated with PHEO/PGL [19, $23,24]$. In addition to a positive family history of PHEO/PGL or evidence of specific syndrome, the presence of multiple primary tumors is an indicator of genetic predisposition. In sporadic cases with a single tumor, early age at diagnosis, malignancy or extra-adrenal location, are risk factors for the presence of a germline mutation. However, many of associated 
genes have incomplete penetrance and/or variable expression [17, 25-28].

Following study gives a view about the occurrence, clinical and laboratory manifestation, localization, histological type and genetic background of PHEO and PGL in Eastern Slovakia.

\section{Patients and methods}

Patients. This observational, both retrospective and prospective, multi centre, cohort study maps the occurrence of PHEO and PGL in Eastern Slovakia region in years 2006 2011. The study included 28 patients ( 18 women and $10 \mathrm{men}$ ), all of them residents of East of Slovakia that were diagnosed by endocrinologists from subregions of Eastern Slovakia and sent to the $1^{\text {st }}$ Department of Internal Medicine of University Hospital Košice, Slovakia.

Diagnosis of PHEO/PGL consisted of history taking, clinical evaluation, laboratory investigations confirming catecholamines overproduction and imaging methods uncovering the morphologic basis of the disease in each of the patient. All patients underwent surgical treatment that also enabled the histological confirmation of the diagnosis. Based on the clinical, laboratory, morphologic and histological features, genetic analysis was performed in order to reveal hereditary / familial forms of PHEO/PGL in suspect cases.

Methods. History taking and clinical evaluation was focused on the presence of hypertension, its duration and character (paroxysmal, sustained), presence of orthostatic hypotension as well as typical clinical symptoms (headache, palpitations, sweating) and other symptoms associated with catecholamines overproduction (pallor, nausea, weight loss, tiredness, anxiety, etc.). In the meantime, basic investigation oriented on other clinical features of hereditary syndromes associated with PHEO/PGL (VHL, NF-1, MEN-2) was performed. Moreover, presence of other endocrinopathies (except for those known to be associated with PHEO/PGL) as well as other severe comorbidities (e.g. myocardial infarction, arrhythmias, heart failure, stroke, diabetes mellitus, etc.) was assessed. At last, but not at least, family history of PHEO/PGL, malignant hypertension or sudden death possibly related to PHEO/PGL as well as familial medullar thyroid cancer (FMTC) was evaluated.

Laboratory assessment followed clinical evaluation and except for basic hematological and biochemical parameters included examination focused on confirmation of catecholamines overproduction. Biochemical diagnosis of PHEO/PGL consisted of measurement of plasma free metanephrines - metanephrine $(\mathrm{MN})$ and normetanephrine (NMN), vanyllilmandelic acid (VMA), chromogranin A (CGA), neuron specific enolase (NSE). Free plasma metanephrines were assessed using high pressure liquid chromatography, VMA using spectrophotometry, CGA and NSE radioimunoanalytically using kits in RIA Laboratory in Košice. Since there is no possibility to obtain clonidine for diagnostic or therapeutic use in Slovakia, clonidine suppression test was not included in diagnostic protocol.
Imaging methods included ultrasound (US), computed tomography (CT) or magnetic resonance imaging (MRI). In controversial cases or when extra-adrenal and malignant PHEO/PGL was suspect, ${ }^{131}$ I-labeled meta-iodobenzylguanidine $\left({ }^{131} \mathrm{I}-\mathrm{MIBG}\right)$ scintigraphy and ${ }^{18}$ fluorodeoxyglucose positron emission tomography $\left({ }^{18} \mathrm{FDG}-\mathrm{PET}\right)$ in combination with computed tomography $\left({ }^{18} \mathrm{FDG}-\mathrm{PET} / \mathrm{CT}\right)$ were performed.

Histological diagnosis followed surgical procedures in all patients and except for histological criteria, immunohistochemical analyses including CGA clone LK2H1, S-100 protein clone 15E2E2 and Synaptophysin clone Snp 88 using Biogenex kits were performed.

Genetic testing for RET, VHL gene mutations was performed at Department of medical genetics, Oncological Institute of Saint Elisabeth in Bratislava. Since there is no possibility for SDHx gene germline mutations testing in Slovakia, mutations of these genes were analysed in National Institutes of Health (NIH) in Bethesda, MD, USA.

Statistical analysis was performed using statistical program SPSS Statistics, version 17.0. As this is only a non-comparative study (without control group), methods of descriptive statistics were used mainly. Continuous variables are presented as mean \pm standard deviation (SD), categorical variables are expressed as numbers or percentage of patients. The multivariable association was analyzed with linear regression analysis and $P$-value $<0,05$ was considered statistically significant.

\section{Results}

Mean age at the time of the diagnosis was $46,9 \pm 14,8$ years with the range from 20 to 71 years. Mean approximate time of the duration from the first symptoms to the diagnosis was 4,4 $\pm 1,2$ years, with the range from 2 months to 20 years (patient with sustained hypertension).

Symptoms of patients with PHEO/PGL are shown in the Table 1. Arterial hypertension was the most frequent clinical presentation of the disease with slightly higher occurrence of

Table 1. Clinical presentation according to the frequency of symptoms.

\begin{tabular}{|c|c|c|c|}
\hline \multicolumn{2}{|l|}{ Symptom } & \multicolumn{2}{|l|}{ n (\%) } \\
\hline \multirow[t]{2}{*}{ Arterial hypertension } & Paroxysmal & \multirow[t]{2}{*}{$24(86 \%)$} & $14(58 \%)$ \\
\hline & Sustained & & $10(42 \%)$ \\
\hline \multicolumn{2}{|l|}{ Orthostatic hypotension } & $5(18 \%)$ & \\
\hline \multicolumn{2}{|c|}{ Adrenal incidentaloma - asymptomatic } & $3(11 \%)$ & \\
\hline \multicolumn{2}{|l|}{ Cephalea } & $18(64 \%)$ & \\
\hline \multicolumn{2}{|l|}{ Palpitations, tachycardia } & $16(57 \%)$ & \\
\hline \multicolumn{2}{|l|}{ Sweating } & $15(54 \%)$ & \\
\hline \multirow{2}{*}{\multicolumn{2}{|c|}{$\begin{array}{l}\text { Abdominal discomfort, pain, nausea, vomiting, etc. } \\
\text { Psychic symptoms (anxiety, fear, jitter, etc.) }\end{array}$}} & $12(43 \%)$ & \\
\hline & & $10(39 \%)$ & \\
\hline \multicolumn{2}{|l|}{ Pallor } & $9(32 \%)$ & \\
\hline \multicolumn{2}{|l|}{ Chest pain } & $8(28 \%)$ & \\
\hline \multicolumn{2}{|l|}{ Hot flushes } & $6(21 \%)$ & \\
\hline
\end{tabular}


its paroxysmal form. The mean arterial pressure was $126,1 / 68,1$ $\pm 23,6 / 36,5$ torr, maximal blood pressure 175,5/101,4 $\pm 37,9$ / 17,4 torr, minimal blood pressure 107,1/ 60,8 $\pm 11,5 / 6,7$ torr. In 3 cases $(10,7 \%)$, the diagnosis was gained after differentiation of adrenal incidentaloma in asymptomatic patients.

Apart from arterial hypertension, thyroid diseases were the most frequent associated morbidity in our study. They occured in $20(71,4 \%)$ of all patients with PHEO/PGL. Ten patients $(35,7 \%)$ had autoimmune thyroiditis, 5 of them were euthyroid, 4 hypothyroid and one patient had thyrotoxicosis, respectively. Five patients (17,8\%), member of 2 families suffered from FMTC with a need of surgical treatment and were therefore classified as MEN-2A syndrome. Other 4 patients $(14,3 \%)$ had benign nodular goiter and one patient $(3,6 \%)$ had benign cystic goiter.

Impairment of glucose metabolism was the second most frequent co-morbidity affecting 11 patients (39,3\%). Type 2 diabetes mellitus was diagnosed in 10 patients, 6 of them were treated with oral antidiabetic drugs (OAD), 2 with insulin and

Table 2. Mean values of laboratory parameters and their range.

\begin{tabular}{lll}
\hline Parameter: & Mean \pm SD & Range \\
\hline Plasma free metanephrine $(\mathrm{pg} / \mathrm{ml})$ & $650,3 \pm 787,1$ & $21-3000$ \\
Plasma free normetanephrine $(\mathrm{pg} / \mathrm{ml})$ & $2023,2 \pm 2654,7$ & $87-10298$ \\
Vanylmandelic acid $(\mathrm{mg} / 24 \mathrm{~h})$ & $769,5 \pm 1206$ & $62-2162,5$ \\
Chromogranin A $(\mathrm{ng} / \mathrm{ml})$ & $501,0 \pm 377,6$ & $67-1170$ \\
NSE $(\mathrm{ng} / \mathrm{ml})$ & $11,26 \pm 5,121$ & $5-19$ \\
\hline
\end{tabular}

Table 3. Localization of PHEOs/PGLs.

\begin{tabular}{|c|c|c|}
\hline Localization & & n (\%) \\
\hline \multirow{3}{*}{$\begin{array}{l}\text { Adrenal } \\
23(82,1 \%)\end{array}$} & Left & $10(35,7 \%)$ \\
\hline & Right & $10(35,7 \%)$ \\
\hline & Bilateral & $3(10,7 \%)$ \\
\hline \multirow{3}{*}{$\begin{array}{l}\text { Extra-adrenal } \\
7(25 \%)\end{array}$} & Retroperitoneum & $5(17 \%)$ \\
\hline & Upper+back mediastinum & $1(3,6 \%)$ \\
\hline & Small pelvis and left inguine & $1(3,6 \%)$ \\
\hline
\end{tabular}

2 with diet. 1 patient was classified to have impaired glucose tolerance.

Apart from FMTC (5 patients with MEN-2A syndrome), 4 patients $(14,3 \%)$ had also other malignancy. Two women underwent ovariohysterectomy, one due to myomatous uterus (patient with T2DM) and another due to coincidence of myomatous uterus and teratoma of the ovary. One patient suffered from prostatic cancer. One patient with MEN-2A (bilateral adrenal PHEOs and 3 extraadrenal abdominal PGLs + FMTC, with 3 family members with FMTC) died because of non-small cell lung carcinoma.

Mean values of laboratory parameters in patients with $\mathrm{PHEO} / \mathrm{PGL}$ are demonstrated in the Table 2. In general, mean levels of both, MN and NMN were approximately 8 times above their superior limits. Also CGA was present in high concentrations ( 5 times above its superior limit) and showed to have a positive correlation with the size of the tumor $(\mathrm{r}=0,768 ; \mathrm{p}=0,01)$.

CT was the major method used in order to localize the tumor and was performed in every patient. Although it was reliable in uncovering the primary tumor (100\%), it failed to reveal real size of the affection in 3 patients with extra-adrenal malignant tumor. ${ }^{131} \mathrm{I}-\mathrm{MIBG}$ scintigraphy was used in 14 patients (50\%) and was helpful in localization in 13 cases $(92,9 \%)$. Functional imaging with ${ }^{18} \mathrm{FDG}-\mathrm{PET} / \mathrm{CT}$ was used in 2 cases for detection of metastases.

Distribution of PHEOs/PGLs depending on its location is shown in Table 3. There was no difference between the affection of right and left adrenal gland. All 3 bilateral PHEOs were found in patients with MEN-2A syndrome, members of 2 families, however with the simultaneous presence of 3 retroperitoneal PGLs in one case and extra-adrenal relapse of the disease in another.

Table 4 shows all therapeutic modalities used in our patients. Every patient with PHEO/PGL underwent surgical treatment. However, tumors were non-resecable in 2 patients and only explorative laparotomy with the biopsy and surgical chemoembolization was performed, respectively. Patient with infiltrative left retroperitoneal PGL underwent huge laparotomic resection of primary tumor including left nephrectomy, left adrenalectomy (without confirmation

Table 4. Type of the treatment.

\begin{tabular}{|c|c|c|c|c|}
\hline Type of treatment & & & n (\%) & \\
\hline \multirow{6}{*}{ Surgical } & Laparoscopic adrenalectomy & & $12(39,3 \%)$ & \\
\hline & Laparotomic adrenalectomy & unilateral & $10(35,7 \%)$ & $7(25 \%)$ \\
\hline & & bilateral & & $3(10,7 \%)$ \\
\hline & Laparotomic extirpation/resection of PGL & & $4(14,2 \%)$ & \\
\hline & Mediastinoscopic/-tomic resection of PGL & & $1(3,6 \%)$ & \\
\hline & Chemoembolization & & $1(3,6 \%)$ & \\
\hline Therapeutic ${ }^{131} \mathrm{I}-\mathrm{MIBG}$ & & & $2(7,1 \%)$ & \\
\hline Adjuvant chemotherapy (CVD) & & & $2(7,1 \%)$ & \\
\hline External radiotherapy & & & $1(3,6 \%)$ & \\
\hline
\end{tabular}


of PHEO), left colectomy with colorectal anastomosis and lymphadenectomy. Patient with infiltrative mediastinal PGL underwent several operations in order to minimalize the tumor (mediastinoscopy, mediastinotomy, partial resection of tumor, tracheostomy, stabilizing operation of vertebras), however required also therapeutic application of ${ }^{131} \mathrm{I}$-MIBG. Therapeutic ${ }^{131}$ I-MIBG and chemotherapy using CVD therapeutic protocol (cyclophosphamid, vincristin, dacarbasin) followed surgical treatment in patient with metastatic retroperitoneal PGL. Patient with non-resecable metastatic pelvic/inguinal PGL underwent CVD chemotherapy and external radiotherapy (vertebral metastases).

Mean size of the tumor was $66,2 \pm 39,3 \mathrm{~mm}$, with a range from 25 to $200 \mathrm{~mm}$. Histological diagnosis was obligatory in each patient. Apart from basic pathological evaluation, immunohistochemical analysis was performed in the majority of patients showing an absolute positivity in examined cases (Table 5.)

Based on the patient's history, clinical presentation, biochemical analysis, imaging methods and histological diagnosis, 23 patients were recognized to have PHEO $(82,1 \%)$ and 6 patients PGL (21,4\%). According to the presence, localization and multiplicity of metastases and/or infiltrative growth/invasion, 23 patients $(82,1 \%)$ were classified to have benign form of the disease and 5 patients $(14,3 \%)$ as malignant. The most frequent localization of metastases was lymphatic nodes, liver, lungs and bones, respectively.

Nine patients of $28(32,1 \%)$ were confirmed to have hereditary form of PHEO/PGL. 5 patients (17,8\%), members of 2 families (4+1) were classified as MEN-2A syndrome. In these 2 families, genetic screening for RET gene mutation was part of the diagnostic protocol and confirmed $(1+1)$ or revealed the disease $(1+0)$, or answered the question of further follow up and early treatment in previously asymptomatic patients $(2+0)$, respectively. FMTC with a need of thyroidectomy occurred before or after manifestation of PHEO/PGL. However, RET gene mutation and FMTC with a need of surgical treatment but without confirmed PHEO/PGL was found also in 3 of 4 members of the second family (of patient with FMTC, bilateral PHEO and 3 retroperitoneal PGLs). Germline mutations of SDHB gene were present in 4 of 7 examined patients $(14,3 \%$ of total patients): in patient with infiltrative mediastinal PGL, patient with metastatic retroperitoneal PGL, patient with metastatic pelvic/inguinal PGL and patient with non-resecable PHEO of right adrenal gland. However, further genetic screening in the families of patients with mediastinal PGL and non-resecable PHEO revealed another $3+2$ family members with positive SDHB gene mutation respectively, although without further confirmation of the diagnosis of PHEO/PGL. Remaining 19 patients with PHEO/PGLs were considered to have non-familial form.

\section{Discussion}

This multi centre observational study of PHEO/PGL from Eastern Slovakia region represents one of the biggest studies
Table 5. Immunohistochemical analyses of tumors.

\begin{tabular}{lc}
\hline Immunohistochemical parameter & Positivity \\
\hline CGA clone LK2H1 & $100 \%$ \\
S-100 protein clone 15E2E2 & $100 \%$ \\
Synaptophysin clone Snp 88 & $100 \%$ \\
\hline
\end{tabular}

on PHEO/PGL in a geographic area to date. However, we suppose that the true prevalence of PHEO/PGL could be higher as not all endocrinologists from Eastern Slovakia participated on the study. Moreover, thanks to variable clinical and laboratory presentation of the disease, the diagnosis will be missed if not suspected yet in primary care.

In our study, we have registered a much higher prevalence of PHEO/PGL in women than men (18 vs. 10, representing $64.3 \%$ vs. $35,7 \%$, respectively). Arterial hypertension (AH) was the major symptom present in $86 \%$ of patients with slight dominance of paroxysmal form (58\%). In 3 cases (10,7\%), the diagnosis was gained after differentiation of adrenal incidentaloma in asymptomatic patients. According to the current data, PHEO/PGL can be found in 1,5-23\% of adrenal incidentalomas [29]. Also frequency of other symptoms, as well as efficacy of laboratory and imaging methods used for the diagnosis were comparable with literature data $(1,2,16)$. We confirm CGA to be a good marker for a size of the tumor mass [30].

However, we have found relatively high prevalence of other co-morbidities, especially thyroid diseases that were present in $71,4 \%$, which has not been described in such quantity yet. In fact, apart from FMTC and MEN-2A syndrome, there are no data about the association between pheochromocytoma and other thyroid diseases. In our study, autoimmune thyroiditis with all its clinical forms (euthyroidism, hypothyroidism, thyrotoxicosis) was even more frequent than FMTC $(17,8 \%)$, affecting $35,7 \%$ of patients. Perhaps, dominantly female distribution of our group could give us one of the explanations. Furthermore, we have found relatively high occurrence $(39,3 \%)$ of glucose metabolism impairment as well. Although, the effects of catecholamines on insulin secretion and glucose metabolism is well known [31-36], there are only few data about long-term effects or association with diabetes mellitus [37-40]. However, a number of glucose metabolism disorders in this multi centre study could be higher, as some patients joined the group after they had undergone the treatment because of the severity of the disease and without previous proper examination for glucose metabolism disturbances. The same as it was in the case of lipid metabolism evaluation that we had to exclude from the analysis due to the lack of the data.

Interestingly, apart from FMTC $(17,8 \%)$ the patients suffered also from other malignancies $(14,3 \%)$, representing altogether $32,1 \%$. Together with the bigger size of the primary tumor $(6,6 \mathrm{~cm})$, higher concentrations of metanephrines (8 times above their superior limit) high prevalence of extraadrenal tumors (25\%), malignant (14,3\%) and hereditary forms 
$(32,1 \%)$, we suppose a possible contribution of genetic and environmental factors of this geographical region, however this requires further evaluation. Since the genetic testing was performed only in 12 of all patients $(42,9 \%)$, in this context it would be valuable to examine other patients from the study group as well, at least all those with features associated with higher risk (see above). On the other hand, thanks to genetic diagnosis, further genetic screening in the families of positive patients revealed another mutation positive members of 4 families (in both families with RET gene mutations and in 2 families with SDHB gene mutations, respectively). In case of patients with MEN-2A syndrome, they enabled to discover and treat tumors yet in asymptomatic individuals. Asymptomatic family members with germline SDHB mutations and without confirmed disease remain in close endocrinological follow up.

Among environmental factors of Eastern Slovakia that might play role in the pathogenesis of various diseases, polychlorinated biphenyls (PCBs) represent the most discussed ones. Region of Eastern Slovakia counts to the regions with the highest pollution of PCBs in the world [41]. PCBs represent persistent organic pollutants with a variety of known serious health effects such as cancer and a number of noncarcinogenic effects. Depending on the character, amount and severity of the pollution of PCBs and their coexistence with human, they may either participate on the expression and penetration of pre-existed inherited mutations, or even show mutagenic effects. Influence of PCBs on thyroid gland, metabolism and immunity in the population from this area has been already described [42-57] and higher prevalence of the thyroid diseases and impairment of glucose metabolism in our patients with $\mathrm{PHEO} / \mathrm{PGL}$ could be the clue to their possible etiopathogenetic role.

\section{Conclusion}

This multi center observational study gives a view about the occurrence, clinical and laboratory presentation, localization, histological type and genetic background of PHEO/PGL in Eastern Slovakia. It reports relatively high occurrence of thyroid diseases, impairment of glucose metabolism and other malignancy in patients with PHEO/PGL, which has not been described yet. Together with a bigger size of the primary tumor, higher concentrations of metanephrines and prevalence of extra-adrenal tumors, malignant and hereditary forms, we suppose genetic and environmental factors of this region may play a role in the etiopathogenesis. However this requires a further evaluation.

Acknowledgments: We would like to thank to the regional endocrinologists (in alphabetical order): Filipová J, MD; Hrabčáková J, MD; Kríž O, MD; Michalides M, MD; Pávai D sen., MD; Pávai D. jr, MD; Švajdlerová A, MD; Timko V, MD; Tokarčíková A, MD; for their participation and involving their patients in the study. We would like to thank also to Žemberová E, PharmDr. and RIA Laboratory in
Košice for laboratory analyses in our patients. At last, but not least we would like to thank to Prof. Pacák K, MD, PhD and NIH, Bethesda, MD, USA for genetic testing of SDHx gene mutations and for their diagnostic and therapeutic help in our patients with malignant PHEO/PGL as well as to Department of medical genetics, Oncological Institute of Saint Elisabeth in Bratislava for genetic analysis of RET gene mutations in patients with MEN-2 syndrome.

\section{References}

[1] LENDERS JW, EISENHOFER G, MANNELLI M, PACAK K. Phaeochromocytoma. Lancet 2005; 366: 665-675.

[2] PACAK K, LINEHAN WM, EISENHOFER G, WALTHER MM, GOLDSTEIN DS. Recent advantages in genetics, diagnosis, localization, and treatment of pheochromocytoma. Ann Intern Med 2001; 134: 315-29.

[3] ELDER EE, ELDER G, LARSSON C. Pheochromocytoma and functional paraganglioma syndrome: no longer the 10\% tumor. J Surg Oncol 2005; 89: 193-201. http://dx.doi. org/10.1002/jso.20177

[4] PACAK K, CHROUSOS GP, KOCH CA, LENDERS JW, EISENHOFER G. Pheochromocytoma: progress in diagnosis, therapy and genetics. In: Margioris A, Chrousos GP (eds) Adrenal disorders 2001; 1 ed. Humana Press, Totowa, pp. 479-523.

[5] MANGER WM, GIFFORD RW. Pheochromocytoma. J Clin Hypertens 2002, 4: 62-72. http://dx.doi.org/10.1111/j.1524$\underline{6175.2002 .01452 . x}$

[6] BRAVO EL, TAGLE R. Pheochromocytoma: state-of-the-art and future prospects. Endocr Rev 2003, 24: 539-53. http:// dx.doi.org/10.1210/er.2002-0013

[7] O'RIORDAIN DS, YOUNG WF JR., GRANT CS, CARNEY JA, Van HEERDEN JA. Clinical spectrum and outcome of functional extraadrenal paraganglioma. World J Surg 1996; 20: 916-21. http://dx.doi.org/10.1007/s002689900139

[8] GOLDSTEIN RE, O’NEILL JA JR., HOLCOMB GW 3rd, MORGAN WM 3rd, NEBLETT WW 3rd. et al. Clinical experience over 48 years with pheochromocytoma. Ann Surg 1999; 229: 755-766. http://dx.doi.org/10.1097/00000658199906000-00001

[9] EDSTROM EE, HJELM SKOG AL, HOOG A, HAMBERGER $B$. The management of benign and malignant pheochromocytoma and abdominal paraganglioma. Eur J Surg Oncol 2003; 29: 278-83. http://dx.doi.org/10.1053/ejso.2002.1413

[10] EISENHOFER G, BORNSTEIN SR, BROUWERS FM, CHEUNG NK, DAHIA PL et al. Malignant pheochromocytoma: current status and initiatives for future progress. Endocr Relat Cancer 2004; 11: 423-436. http://dx.doi.org/10.1677/ erc. 1.00829

[11] EISENHOFER G, KEISER H, FRIBERG P, MEZEY E, HUYNH TT et al. Plasma metanephrines are markers of pheochromocytoma produced by catechol-O-methyltransferase within tumors. J Clin Endocrinol Metab 1998; 83: 2175-2185. http:// dx.doi.org/10.1210/jc.83.6.2175

[12] EISENHOFER G, HUYNH TT, HIROI M, PACAK K. Understanding catecholamine metabolism as a guide to the biochemical diagnosis of pheochromocytoma. Rev Endocr 
Metab Disord 2001; 2: 297-311. http://dx.doi.org/10.1023/ A:1011572617314

[13] LENDERS JW, PACAK K, WALTHER MM, LINEHAN WM, MANNELLI $\mathrm{M}$ et al. Biochemical diagnosis of pheochromocytoma: which test is best? JAMA 2002; 287: 1427-1434. http://dx.doi.org/10.1001/jama.287.11.1427

[14] EISENHOFER G, GOLDSTEIN DS, WALTHER MM, FRIBERG P, LENDERS JW et al. Biochemical diagnosis of pheochromocytoma: How to distinguish true- from false positive test results. J Clin Endocrinol Metab 2003; 88: 2656-2666. http://dx.doi.org/10.1210/jc.2002-030005

[15] EISENHOFER G, LENDERS JW, GOLDSTEIN DS, MANNELLI M, CSAKO G et al. Pheochromocytoma catecholamine phenotypes and prediction of tumor size and location by use of plasma free metanephrines. Clin Chem 2005; 51: 735-744. http://dx.doi.org/10.1373/clinchem.2004.045484

[16] PACAK K, EISENHOFER G, AHLMAN H, BORNSTEIN SR, GIMENEZ-ROQUEPLO AP et al. Pheochromocytoma: recommendations for clinical practice from the First International Symposium. Nat Clin Pract Endocrinol Metab 2007; 3: 92-102.

[17] EISENHOFER G, TISCHLER AS, KRIJGER RR. Diagnostic tests and biomarkers for pheochromocytoma and extra-adrenal paraganglioma: from routine laboratory methods to disease stratification. Endocr Pathol 2012; 23: 4-14. http:// dx.doi.org/10.1007/s12022-011-9188-1

[18] NEUMANN HP, BAUSCH B, McWHINNEY SR, BENDER BU, GIMM O et al. (Freiburg-Warsaw-Columbus Pheochromocytoma Study Group). Germ-line mutations in nonsyndromic phehochromocytoma. N Engl J Med 2002; 346 : 1459-66. http://dx.doi.org/10.1056/NEJMoa020152

[19] BRYANT J, FARMER J, KESSLER LJ, TOWNSEND RR, NATHANSON KL. Pheochromocytoma: the expanding genetic differential diagnosis. J Natl Cancer Inst 2003; 95: 1196-204. http://dx.doi.org/10.1093/jnci/djg024

[20] MULLIGAN LM, KWOK JB, HEALEY CS, ELSDON MJ, ENG C et al. Germ-line mutations of the RET proto-oncogene in multiple endocrine neoplasia type 2A. Nature 1993; 363: 458-60. http://dx.doi.org/10.1038/363458a0

[21] LATIF F, TORY K, GNARRA J, YAO M, DUH FM et al. Identification of the von Hippel-Lindau disease tumor suppressor gene. Science 1993; 260: 1317-20. http://dx.doi.org/10.1126/ science. 8493574

[22] SHEN MH, HARPER PS, UPADHYAYA M. Molecular genetics of neurofibromatosis type 1 (NF1). J Med Genet 1996; 33: 2-17. http://dx.doi.org/10.1136/jmg.33.1.2

[23] YAO L, SCHIAVI F, CASCON A, QIN Y, INGLADA-PÉREZ L et al. Spectrum and prevalence of FP/TMEM127 gene mutations in pheochromocytomas and paragangliomas. JAMA 2010; 304(23): 2611-9. http://dx.doi.org/10.1001/jama.2010.1830

[24] BURNICHON N, CASCON A, SCHIAVI F, MORALES NP, COMINO-MÉNDEZ I et al. MAX mutations cause hereditary and sporadic pheochromocytoma and paraganglioma. Clin Cancer Res 2012; 18(10): 2828-37. http://dx.doi.org/10.1158/ 1078-0432.CCR-12-0160

[25] BORNSTEIN SR, GIMENEZ-ROQUEPLO AP. Genetic testing in pheochromocytoma: Increasing importance for clinical decision-making. Ann NY Acad Sci 2006; 1073: 94-103. http://dx.doi.org/10.1196/annals.1353.010

[26] TIMMERS HJLM, KOZUPA A, EISENHOFER G, RAYGADA M, ADAMS KT et al. Clinical presentations, biochemical phenotypes, and gynotype-phenotype correlations in patients with succinate dehydorgenas subunit B-associated pheochromocytomas and paragangliomas. J Clin Endocrinol Metab 2007; 92(3): 779-786.

[27] BROUWERS FM, EISENHOFER G, TAO JJ, KANT JA, ADAMS KT et al. High frequency of SDHB germline mutations in patients with malignant catecholamine producing paragangliomas: implications for genetic testing. J Clin Endocrinol Metab 2006; 91: 4505-4509. http://dx.doi. org/10.1210/jc.2006-0423

[28] JAFRI M, MAHLER ER. The genetics of pheochromocytoma: using clinical features to guide genetic testing. Eur J Endocrinol 2012; 166: 151-158. http://dx.doi.org/10.1530/ EJE-11-0497

[29] MANSMANN G, LAU J, BALK E, ROTHBERG M, MIYACHI Y, BORNSTEIN SR. The clinically inapparent adrenal mass: update in diagnosis and management. Endocr Rev 2004; 25(2): 309-340. http://dx.doi.org/10.1210/er.2002-0031

[30] D'HERBOMEZ M, GOUZE V, HUGLO D, NOCAUDIE M, PATTOU F et al. Chromogranin A assay and (131)I-MIBG scintigraphy for diagnosis and follow-up of pheochromocytoma. J Nucl Med 2001; 42: 993-997

[31] BRAVO E. Evolving concepts in the pathophsiology, diagnosis and treatment of pheohromocytoma. Endocr Rev 1994; 15: 356-368.

[32] COLWELL JA. Inhibition of insulin secretion by catecholamines in pheochromocytoma. Ann Intern Med 1969: 71: 251-6.

[33] HAMAJI M. Pancreatic alpha- and beta-cell function in pheochromocytoma. J Clin Endocrinol Metab 1979; 49: 322-5. http://dx.doi.org/10.1210/jcem-49-3-322

[34] CHIASSON JL, SHIKAMA H, CHU DT, EXTON JH. Inhibitory effect of epinephrine on insulin-stimulated glucose uptake by rat skeletal muscle. J Clin Invest 1981; 68: 706-13. http://dx.doi.org/10.1172/JCI110306

[35] ROSEN SG, CLUTTER WE, SHAH SD, MILLER JP, BIER $\mathrm{DM}$ et al. Direct alpha-adrenetic stimulation of hepatic glucose production in human subjects. Am J Physiol 1983; 245: E616-26.

[36] DI PAOLO S, DE PERGOLA G, COSPITE MR, GUASTAMACCHIA E, CIGNARELLI $M$ et al. Beta-adrenoreceptors desensitization may modulate catecholamine induced insulin resistance in human pheochromocytoma. Diabete Metab 1989: 15: 409-15.

[37] BATIDE-ALANORE A, CHATELLIER G, PLOUIN PF. Diabetes as a marker of pheochromocytoma in hypertensive patients. J Hypertens 2003; 21: 1703-07. http://dx.doi. org/10.1097/00004872-200309000-00020

[38] EDELMAN ER, STUENKEL CA, RUTHERFORD JD, WILLIAMS GH. Diabetic ketoacidosis associated with pheochromocytoma. Cleve Clin J Med 1992; 59: 423-7.

[39] ISOTANI H, FUJIMURA Y, FURUKAWA K, MORITA K. Diabetic ketoacidosis associated with the pheochromocytoma 
of youth. Diabetes Res Clin Pract. 1996; 34(1): 57-60. http:// dx.doi.org/10.1016/S0168-8227(96)01330-7

[40] ISHII C, INOURE K, NEGISHI K, TANE N, AWATA T et a. Diabetic ketoacidosis in a case of pheochromocytoma. Diabetes Res Clin Pract. 2001; 54(2): 137-42. http://dx.doi. org/10.1016/S0168-8227(01)00261-3

[41] KOCAN A, PETRÍK J, JURSA S, CHOVANCOVA J, DROBNA B. Environmental contamination with polychlorinated biphenyls in the area of their former manufacture in Slovakia. Chemosphere. 2001; 43(4-7): 595-600. http://dx.doi. org/10.1016/S0045-6535(00)00411-2

[42] LANGER P, TAJTAKOVA M, FODOR G, KOCAN A, BOHOV $P$ et al. Increased thyroid volume and prevalence of thyroid disorders in an area heavily polluted by polychlorinated biphenyls. Eur J Endocrinol. 1998; 139(4): 402-9. http://dx.doi. org/10.1530/eje. 0.1390402

[43] LANGER P, KOCAN A, TAJTAKOVA M, PETRÍK J, CHOVANCOVA J et al. Possible effects of polychlorinated biphenyls and organochlorinated pesticides on the thyroid after long-term exposure to heavy environmental pollution. J Occup Environ Med. 2003; 45(5): 526-32. http://dx.doi. org/10.1097/01.jom.0000058346.05741.b0

[44] LANGER P, KOCAN A, TAJTAKOVA M, PETRÍK J, CHOVANCOVA J et al. Human thyroid in the population exposed to high environmental pollution by organochlorinated pollutants for several decades. Endocr Regul. 2005; 39(1): 13-20.

[45] LANGER P, TAJTAKOVA M, KOCAN A, VLCEK M, PETRÍK $J$ et al. Multiple organochlorine pollution and the thyroid. Endocr Regul. 2006; 40 (2): 46-52.

[46] LANGER P, TAJTAKOVA M, KOCAN A, PETRÍK J, KOSKA J, et al. Thyroid ultrasound volume, structure and function after long-term high exposure of large population to polychlorinated biphenyls, pesticides and dioxin. Chemosphere. 2007; 69(1): 118-27. http://dx.doi.org/10.1016/j.chemosphere.200 7.04.039

[47] LANGER P, KOCAN A, TAJTAKOVA M, RADIKOVA Z, PETRÍK J et al. Possible effects of persistent organochlorinated pollutants cocktail on thyroid hormone levels and pituitarythyroid interrelations. Chemosphere. 2007; 70(1): 110-8. http://dx.doi.org/10.1016/j.chemosphere.2007.06.046

[48] RADIKOVA Z, TAJTAKOVA M, KOCAN A, TRNOVEC T, SEBOKOVA E et al. Possible effects of environmental nitrates and toxic organochlorines on human thyroid in highly polluted areas in Slovakia. Thyroid. 2008; 18(3): 353-62. http://dx.doi.org/10.1089/thy.2007.0182
[49] LANGER P. Persistent organochlorinated pollutants (PCB, DDE, HCB, dioxins, furans) and the thyroid--review 2008. Endocr Regul. 2008; 42(2-3): 79-104.

[50] CEBECAUER L, RADIKOVA Z, ROVENSKÝ J, KOSKA, IMRICH $\mathrm{R}$ et al. Increased prevalence and coincidence of antinuclear and antithyroid antibodies in the population exposed to high levels of polychlorinated pollutants cocktail. Endocr Regul. 2009; 43(2): 75-81.

[51] LANGER P, KOCAN A, TAJTAKOVA M, PETRÍK J, CHOVANCOVA $J$ et al. Fish from industrially polluted freshwater as the main source of organochlorinated pollutants and increased frequency of thyroid disorders and dysglycemia. Chemosphere. 2007; 67(9): S379-85. http://dx.doi. org/10.1016/j.chemosphere.2006.05.132

[52] LANGER P, KOCAN A, TAJTAKOVA M, KOSKA J, RADIKOVA $\mathrm{Z}$ et al. Increased thyroid volume, prevalence of thyroid antibodies and impaired fasting glucose in young adults from organochlorine cocktail polluted area: outcome of transgenerational transmission? Chemosphere. 2008; 73(7): 1145-50. http://dx.doi.org/10.1016/i.chemosphere.2008.06.067

[53] LANGER, KOCAN A, TAJTAKOVA M, SUSIENKOVA K, RADIKOVA $\mathrm{Z}$ et al. Multiple adverse thyroid and metabolic health signs in the population from the area heavily polluted by organochlorine cocktail (PCB, DDE, HCB, dioxin). Thyroid Res. 2009; 2(1): 3. http://dx.doi.org/10.1186/1756-6614-2-3

[54] LANGER P, TAJTAKOVA M, GURETZKI HJ, KOCAN A, PETRÍKJ et al. High prevalence of anti-glutamic acid decarboxylase (anti-GAD) antibodies in employees at a polychlorinated biphenyl production factory. Arch Environ Health. 2002; 57(5): 412-5. http://dx.doi.org/10.1080/00039890209601429

[55] UKROPEC J, RADIKOVA Z, HUCKOVA M, KOSKA J, KOCAN A et al. High prevalence of prediabetes and diabetes in a population exposed to high levels of an organochlorine cocktail. Diabetologia. 2010; 53(5): 899-906. http://dx.doi. org/10.1007/s00125-010-1683-2

[56] PAVUK M, CERHAN JR, LYNCH CF, SCHECTER A, PETRÍK $\mathrm{J}$ et al. Environmental exposure to PCBs and cancer incidence in eastern Slovakia. Chemosphere. 2004; 54(10): 1509-20. http://dx.doi.org/10.1016/j.chemosphere.2003.10.038

[57] LANGER P, KOCAN A, DROBNA B, HUCKOVA M, RADIKOVA Z et al. Alpha-fetoprotein, carcinoembryonic antigen and beta2-microglobulin in adult population highly exposed to organochlorinated pollutants (PCB, DDE and HCB). Endocr Regul. 2011; 45(3): 149-55. http://dx.doi. org/10.4149/endo 2011_03_149 